\title{
Arabidopsis thaliana Cells: A Model to Evaluate the Virulence of Pectobacterium carotovorum
}

\author{
Meriam Terta,, ${ }^{1,2}$ Mohamed Kettani-Halabi, ${ }^{1,2}$ Khadija Ibenyassine, ${ }^{1,2}$ Daniel Tran,, ${ }^{1}$ Patrice Meimoun, ${ }^{1}$ \\ Raja Ait M'hand, ${ }^{2}$ Hayat El-Maarouf-Bouteau, ${ }^{3}$ Florence Val, ${ }^{4}$ M. Mustapha Ennaji, ${ }^{2}$ and \\ François Bouteau ${ }^{1}$ \\ ${ }^{1}$ LEM-EA3514-Université Paris Diderot-Paris 7, 2 place Jussieu, 75251 Paris cedex 05, France; ${ }^{2}$ LVHM-Université Hassan \\ II Mohammedia-FSTM, Maroc; ${ }^{3}$ UR5-UPMC, 3 rue Galilée, 94200 Ivry sur Seine, France; ${ }^{4}$ UMR 1099 BIO3P INRA- \\ Agrocampus Ouest-Université Rennes 1, France
}

Submitted 27 March 2009. Accepted 8 October 2009.

\begin{abstract}
Pectobacterium carotovorum are economically important plant pathogens that cause plant soft rot. These enterobacteria display high diversity world-wide. Their pathogenesis depends on production and secretion of virulence factors such as plant cell wall-degrading enzymes, type III effectors, a necrosis-inducing protein, and a secreted virulence factor from Xanthomonas spp., which are tightly regulated by quorum sensing. Pectobacterium carotovorum also present pathogen-associated molecular patterns that could participate in their pathogenicity. In this study, by using suspension cells of Arabidopsis thaliana, we correlate plant cell death and pectate lyase activities during coinfection with different $P$. carotovorum strains. When comparing soft rot symptoms induced on potato slices with pectate lyase activities and plant cell death observed during coculture with Arabidopsis thaliana cells, the order of strain virulence was found to be the same. Therefore, Arabidopsis thaliana cells could be an alternative tool to evaluate rapidly and efficiently the virulence of different $P$. carotovorum strains.
\end{abstract}

Pectobacterium carotovorum (formerly Erwinia carotovora subsp. carotovora) are gram-negative, enteric bacteria that are economically important plant pathogens causing plant soft rot (Perombelon 2002; Toth et al. 2006). Production and secretion of virulence factors are key steps to the pathogenesis of these bacteria. Their primary virulence characteristic is the coordinated production of large amounts of multiple secreted plant cell wall-degrading enzymes (PCWDE). By cleaving structural polymers in the primary cell wall and middle lamella, PCWDE facilitate pathogen colonization and promote exploitation of the environment for nutrients released from killed cells (Toth et al. 2006). The development of maceration symptoms leads to the breakdown of plant tissues and the onset of soft rot disease (Barras et al. 1994; Collmer 1983; HugouvieuxCotte-Pattat et al. 1996). In addition to these PCWDE, P. caro-

\section{Terta and M. Kettani-Halabi participated equally to this work}

Corresponding author: F. Bouteau; E-mail: francois.bouteau@univ-parisdiderot.fr; Telephone: +33 (0)1 442760 44; Fax: +33 (0)1 44277813 .

* The $e$-Xtra logo stands for "electronic extra" and indicates that a supplementary table is published online. tovorum also produce other secreted virulence factors, including type III effectors (Holeva et al. 2004; Kariola et al. 2003), a necrosis-inducing protein (Mattinen et al. 2004; Pemberton et al. 2005), and a secreted virulence factor from Xanthomonas spp. (Corbett et al. 2005). In P. carotovorum, production of PCWDE and the other secreted virulence factors is tightly regulated by $N$-acyl homoserine lactone (AHL) quorum sensing (QS) (Laasik et al. 2006; Toth et al. 2006). QS is a mechanism of cell to cell communication in which a bacterial population coordinately regulates gene expression in response to cell density by the production and detection of the AHL signal (Barnard and Salmon 2007; Perombelon 2002; Toth et al. 2006). Pectobacterium carotovorum, as all gram-negative bacteria, also exhibit pathogen-associated molecular patterns (PAMPs) such as lipopolysaccharides, the major PAMPs of enterobacteria, which could be potential pathogenic determinants (Toth et al. 2006) independent of QS.

Despite this general scheme, $P$. carotovorum strains isolated from host plants world-wide are surprisingly diverse (Duarte et al. 2004; Gross et al. 1991; Seo et al. 2002; Sledi et al. 2000; Yap et al. 2004). Many studies have analyzed the genetic diversity of Pectobacterium species (Aittamaa et al. 2008; Helias et al. 2004; Mäki-Vlakama and Karjalainen 2008; Parent et al. 1996; Sledi et al. 2000); however, the analysis of virulence diversity remains difficult for these bacteria. The objective of this work was to evaluate the virulence of different $P$. carotovorum strains by using Arabidopsis thaliana suspension cells.

\section{RESULTS AND DISCUSSION}

Pectobacterium carotovorum are known to trigger defense responses and cell death in A. thaliana (Kariola et al. 2003). To assess the virulence of $P$. carotovorum, we measured $A$. thaliana cell death by using cultured suspension cells, a convenient material for studying physiological events induced by pathogens or molecules derived from pathogens (Atkinson et al. 1986; Bouizgarne et al. 2006; Errakhi et al. 2008; Reboutier and Bouteau 2008; van Loon et al. 2008). Coculture of $A$. thaliana cells with $10^{8} \mathrm{CFU}$ of $P$. carotovorum $132 \mathrm{C}$ per milliliter led to a biphasic increase in plant cell death, i.e., a rapid but limited increase during the first $4 \mathrm{~h}$, followed by a large exponential increase leading to death of all A. thaliana cells after $10 \mathrm{~h}$ (Fig. 1A). No significant increase in cell death was observed for control cultures with plant cells alone or those infected with heat-killed bacteria at a rate of $10^{8} \mathrm{CFU} \cdot \mathrm{ml}^{-1}$ 

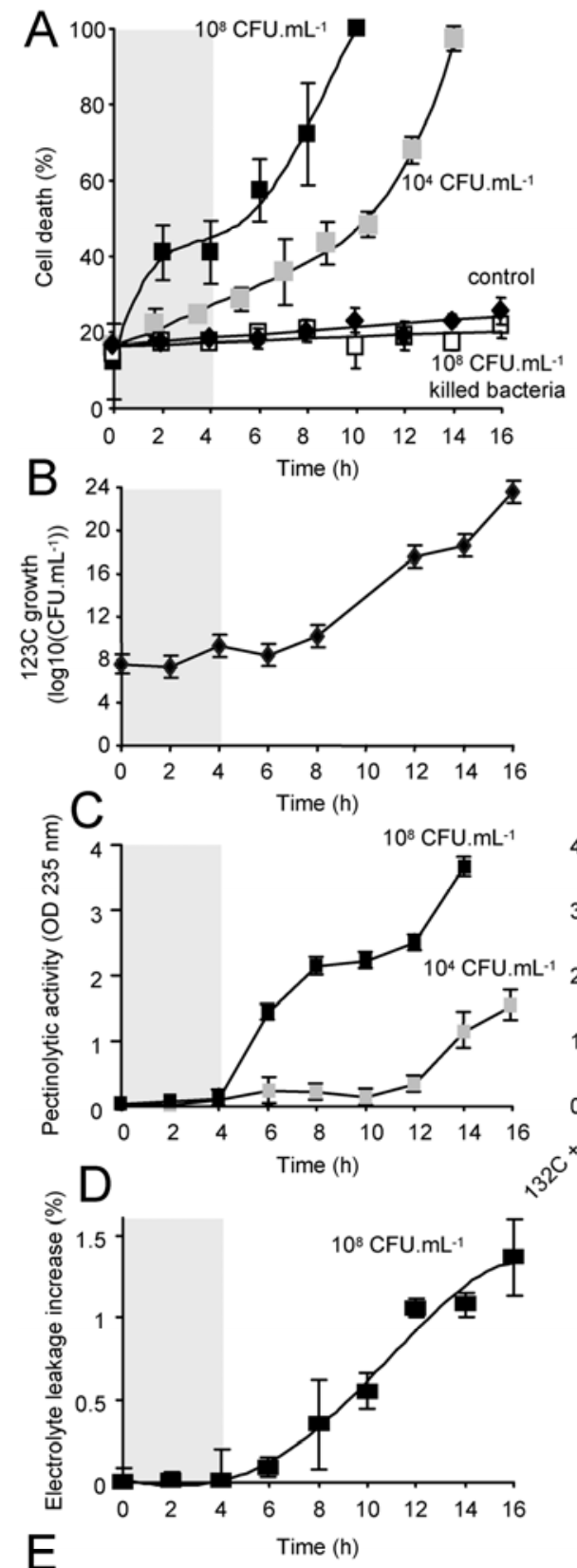

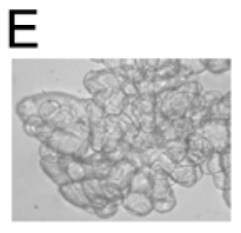

control

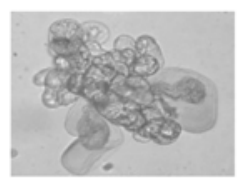

$3 \mathrm{~h}$

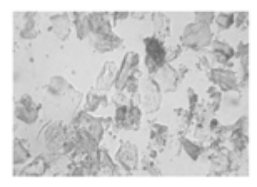

$12 \mathrm{~h}$
Fig. 1. A, Time course of Arabidopsis thaliana cell death after inoculation with Pectobacterium carotovorum $132 \mathrm{C}$ at rates of either $10^{8}$ or $10^{4}$ $\mathrm{CFU} \cdot \mathrm{ml}^{-1}$. Controls were made with plant cells alone or cells infected with heat-killed bacteria $\left(10^{8} \mathrm{CFU} \cdot \mathrm{ml}^{-1}\right)$. B, Time course of the growth of strain $132 \mathrm{C}\left(10^{8} \mathrm{CFU} \cdot \mathrm{ml}^{-1}\right)$ in Gamborg medium without plant cells. C, Time course of pectinoltytic activities (measured by oligogalacturonate accumulation) in the culture medium after innoculation of $A$. thaliana cells with strain $132 \mathrm{C}$ at either $10^{8}$ or $10^{4} \mathrm{CFU} \cdot \mathrm{ml}^{-1}$. Pectinolytic activities measured in culture medium after $14 \mathrm{~h}$ of coculture with $P$. carotovorum at $10^{8}$ CFU. $\mathrm{ml}^{-1}$ compared with strain $132 \mathrm{C}$ alone, plant cells alone, and plant cells infected with heat-killed bacteria $\left(10^{8} \mathrm{CFU} \cdot \mathrm{ml}^{-1)}\right.$. D, Time course of electrolyte leakage increase in the culture medium during coculture of $A$. thaliana cell after inoculation with strain $132 \mathrm{C}$ at $10^{8} \mathrm{CFU} \cdot \mathrm{ml}^{-1}$. E, Light micrographs of $A$. thaliana cells stained with Evans blue before (control) and 3 and $12 \mathrm{~h}$ after inoculation with $P$. carotovorum at $10^{8} \mathrm{CFU} \cdot \mathrm{ml}^{-1}$. Data represent the mean of three independent replicates and error bars correspond to standard errors.
(Fig. 1A). Bacterial growth in the plant cell medium $\left(10^{8}\right.$ $\mathrm{CFU} \cdot \mathrm{ml}^{-1}$ without $A$. thaliana cells; Fig. $1 \mathrm{~B}$ ) was found to be delayed and began after $6 \mathrm{~h}$. This indicated that the observed plant cell death was dependent on events induced by the coculture and could not be ascribed to a simple increase of bacteria in the culture medium. When the coculture was made with strain $132 \mathrm{C}$ at $10^{4} \mathrm{CFU} \cdot \mathrm{ml}^{-1}$, cell death increased slightly from the first hours and the exponential increase in cell death was delayed after $10 \mathrm{~h}$ of coculture (Fig. 1A). P. carotovorum is characterized by its ability to produce high levels of PCWDE, especially pectate lyase, which are primarily responsible for the degradation of plant cell-wall components leading to cell death and tissue maceration (Barras et al. 1994; Collmer 1983; Hugouvieux-Cotte-Pattat et al. 1996). An increase in pectate lyase activities, measured by oligogalacturonate accumulation, was effectively detected in the coculture medium about $4 \mathrm{~h}$ after the beginning of coculture with strain $132 \mathrm{C}$ at $10^{8}$ $\mathrm{CFU} \cdot \mathrm{ml}^{-1}$ and this was delayed to $10 \mathrm{~h}$ with a rate of $10^{4}$ $\mathrm{CFU} \cdot \mathrm{ml}^{-1}$ (Fig. 1C). The kinetics of the exponential cell death and pectate lyase activities appear to be correlated (Fig. 1A and $\mathrm{C}$ ), as expected from previous data highlighting the predominant role of PCWDE secretion in $P$. carotovorum virulence (Toth et al. 2006). A 14-h culture of strain 132C alone showed low pectinolytic activities, and this was also observed in controls containing plant cells alone or cells infected with heat-killed bacteria (Fig. 1C, inlet). Such data indicate that
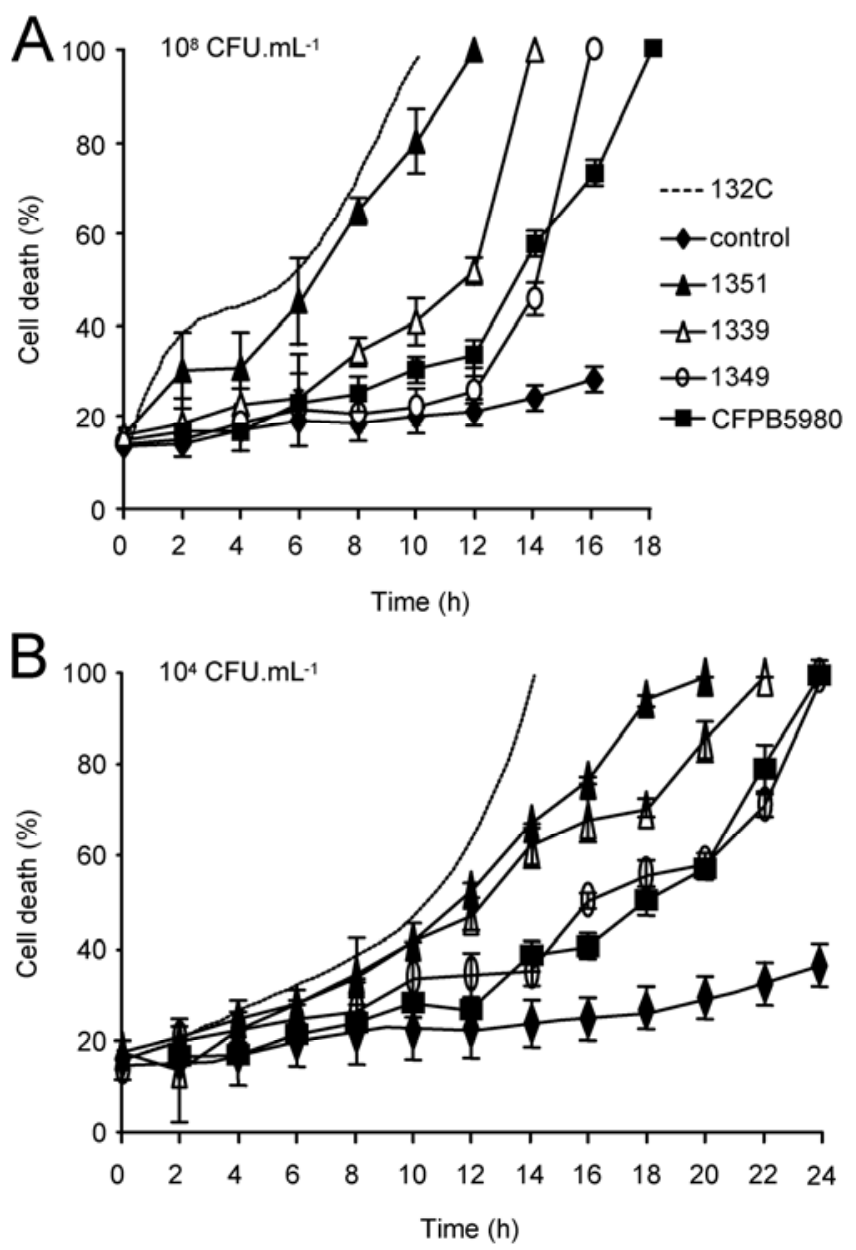

Fig. 2. Time course of Arabidopsis thaliana cell death during coculture after inoculation with Pectobacterium carotovorum strains 1351, 1339, 1349 and CFPB5980 at rates of either A, $10^{8}$ or B, $10^{4} \mathrm{CFU} \cdot \mathrm{ml}^{-1}$. Dashed lines with no symbols correspond to the data of strain $132 \mathrm{C}$. Data represent the mean of three independent replicates and error bars correspond to standard errors. 
PCWDE secretion is linked to the coculture conditions. Previously, it has been shown that production and secretion of PCDWE is activated in the presence of pectin and plant extracts (Barras et al. 1994). An increase in electrolyte leakage, measured as an increase in conductivity of the culture medium, could also be recorded during coculture. This increase in conductivity showed the same kinetics as the change in pectate lyase activities (Fig. 1C and D), and it could be explained by cell breakage as revealed by Evans blue (EB) staining, since cell integrity was not preserved when pectate lyase activities increased (Fig. 1E). These data clearly demonstrate that $P$. carotovorum recognized $A$. thaliana suspension cells as host cells, which allowed the virulence process leading to cell death to be induced.

Upon infection of the suspension cells with $P$. carotovorum 132 C at rates of $10^{8}$ or $10^{4} \mathrm{CFU} \cdot \mathrm{ml}^{-1}$, a small initial increase (of about 30\%) in plant cell death could be seen before the exponential cell-death phase. This initial cell death could not be ascribed to PCWDE secretion, since dead cells only displayed plasmolysis and not cell-wall degradation (Fig. 1E). Moreover, this cell death occurred before pectate lyase activities were detectable (before 4 or $10 \mathrm{~h}$ for $10^{8}$ or $10^{4} \mathrm{CFU} \cdot \mathrm{ml}^{-1}$, respectively; Fig. 1A and $\mathrm{C}$ ). Coculture of cells with heatkilled bacteria did not show any induction of this early and
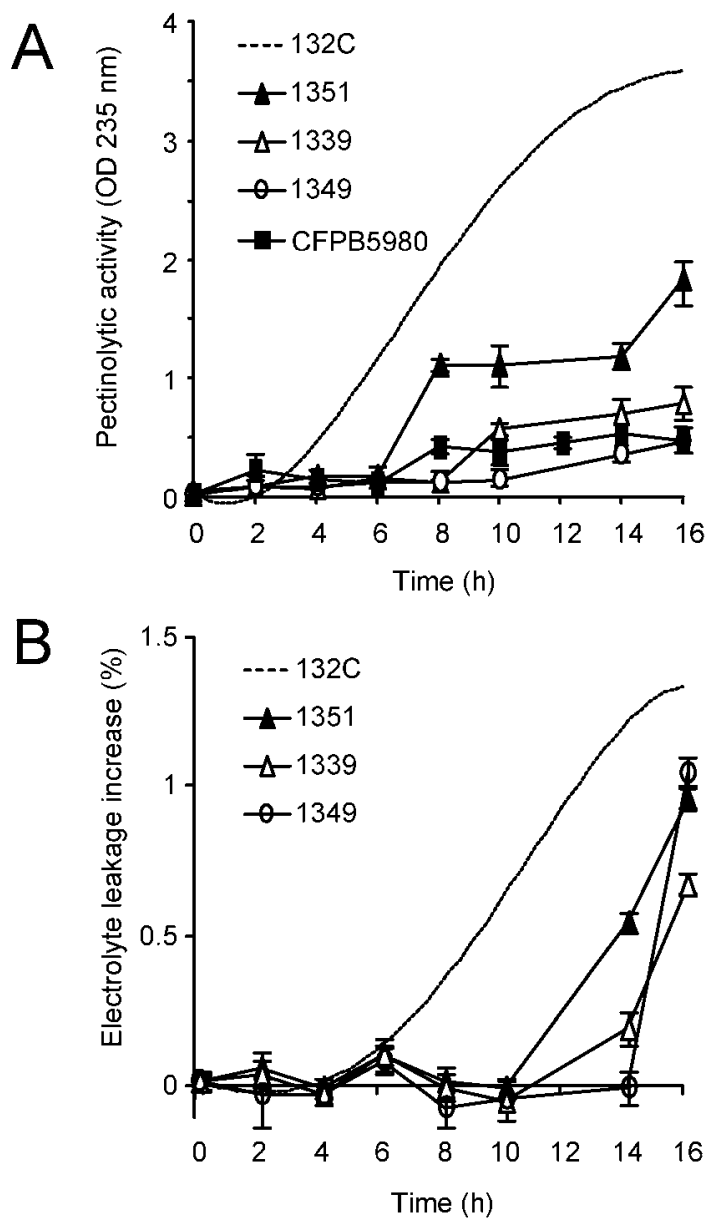

Fig. 3. A, Time course of pectinoltytic activities measured in the culture medium during coculture of Arabidopsis thaliana cell after inoculation with various Pectobacterium carotovorum strains at the rate of $10^{8}$ $\mathrm{CFU} \cdot \mathrm{ml}^{-1}$. B, Time course of electrolyte leakage increase in the culture medium during coculture of $A$. thaliana cell after inoculation with various P. carotovorum strains at $10^{8} \mathrm{CFU} \cdot \mathrm{ml}^{-1}$. Dashed lines with no symbols correspond to the data of strain 132C. Data represent the mean of three independent replicates and error bars correspond to standard errors. limited cell-death phase. This suggests the involvement of one or more factors that are either inactivated by the heat treatment or require active metabolism or bacterial growth. An advantage of this method is to allow parallel and easy measurement of cell death, ion leakage, and enzyme activities in a time-dependent manner. Thus, Arabidopsis thaliana suspension cells are an interesting model to discriminate between the effects of different virulence factors and, more generally, to analyze the virulence of $P$. carotovorum.

The virulence of different $P$. carotovorum strains (Supplemental Table 1) was compared with strain $132 \mathrm{C}$ by measuring the extent of cell death of $A$. thaliana suspension cells cocultured with these strains. When infected with $10^{8} \mathrm{CFU} \cdot \mathrm{ml}^{-1}$, exponential cell death occurred at different times, while an early induced cell death was detected only with strains $132 \mathrm{C}$ and 1351 (Fig. 2A). In this way, strain virulence was found to be as follows: strain $132 \mathrm{C}>1351>1339>1349=$ CFPB5980. The same sequence was observed after infection of $A$. thaliana cells with each strain at the rate of $10^{8} \mathrm{CFU} \cdot \mathrm{ml}^{-1}$, with cell death being delayed as expected for a QS regulation of the virulence (Fig. 2B). We further analyzed the pectate lyase activities of the culture medium upon coculture of $A$. thaliana cells with each $P$. carotovorum strain. As for strain 132C (Fig. 1C), pectate lyase activities were detected after a few hours of coculture (Fig. 3A). The appearance of these activities was correlated with the timing of the exponential cell death (Fig. $2 \mathrm{~A}$ ), thereby allowing us to propose the same sequence of virulence for the different strains: $132 \mathrm{C}>1351>1339>1349=$ CFPB5980. Cell electrolyte leakage during coculture with different strains was also delayed, but it was not perfectly synchronized with either exponential cell death or the increase in pectate lyase activities (Fig. 3B), although it gave the same sequence of virulence. Our comparisons indicate that all the strains are not able to induce an early limited cell death and that the timing of PCWDE secretion and subsequent largescale cell death are variable and strain dependent. Furthermore, this method allows an easy comparison from a relatively large number of samples.

To evaluate the reliability of the data observed using $A$. thaliana suspension cells, the virulence of the different strains was evaluated with potato slices. Twelve potato slices (cv. Agatha) were infected with $P$. carotovorum strains, 132C, 1349, 1359, 1351, and CFPB5980 at $10^{2}, 10^{4}$, or $10^{8} \mathrm{CFU} \cdot \mathrm{ml}^{-1}$. The mean soft-rot diameters were measured after $24 \mathrm{~h}$ (Fig. 4). Infection of potato slices at the rate of $10^{2} \mathrm{CFU} \cdot \mathrm{ml}^{-1}$ showed that the strains fell into the same order when comparing their

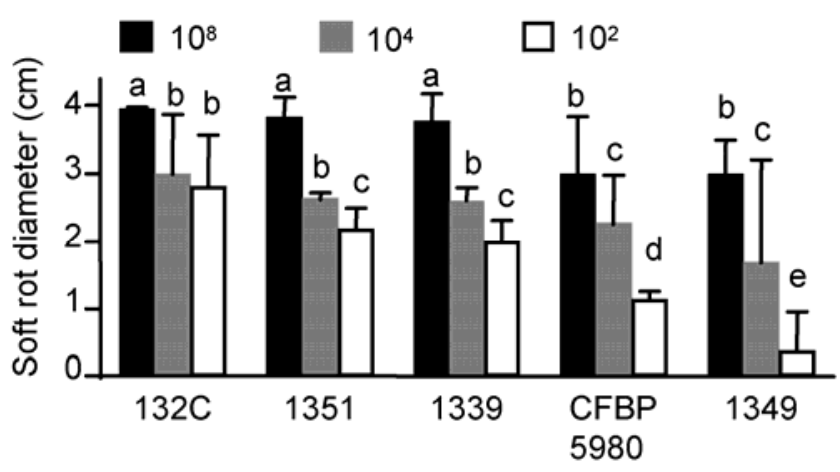

Fig. 4. Mean values of soft-rot diameter caused by the different Pectobacterium carotovorum strains at $10^{2}, 10^{4}$, and $10^{8} \mathrm{CFU} \cdot \mathrm{ml}^{-1}$. Control with sterile distillated water did not induce symptoms. Triplicate potato slices in the same petri dishes were carried out as repeated treatments for each test, error bars correspond to standard errors. For each treatment, variable bar values with the same letter are not significantly different according to Duncan's multiple range, $P \leq 0.05$. 
action on cell death of $A$. thaliana-cultured cells, pectate lyase activities, and virulence on potato slices, i.e., 132C > 1351 > $1339>1349=$ CFPB5980. Even if the differences between strains were not significant for infection at $10^{8}$ and $10^{4}$ $\mathrm{CFU} \cdot \mathrm{ml}^{-1}$, the general trends suggest the same sequence of virulence for the different strains (Fig. 4). Therefore, the celldeath data observed in A. thaliana cells are in accordance with the soft-rot symptoms found with infected potato slices. This cell death is representative of the bacterial virulence and, interestingly allows a precise evaluation of the virulence of different strains.

In conclusion, A. thaliana suspension cells are a reliable model to undertake a rapid testing of virulence diversity. Our data highlight the use of $A$. thaliana suspension cells as a tool to dissect the different events involved in $P$. carotovorum pathogenicity and to evaluate efficiently and rapidly the virulence of different strains.

\section{MATERIALS AND METHODS}

\section{Bacterial material.}

Different strains of $P$. carotovorum, formerly $E$. carotovora subsp. carotovora, previously characterized by the Moroccan team, were used in this study and compared with the reference strain CFPB5980. All strains display the biochemical characteristics of $P$. carotovorum. PCR amplifications of total genomic DNA from all strains were positive with the primers $\mathrm{Y} 1$ and $\mathrm{Y} 2$, specific for Pectobacterium species (Darrasse et al. 1994) (amplified fragment of $434 \mathrm{bp}$ ), and they were negative with primers P143 and P145, specific for Dickeya chrysanthemi (El Hassouni et al. 1999). Strains were stored at $-80^{\circ} \mathrm{C}$. When required, each bacterial strain was cultured on LPGA agar medium $(5 \mathrm{~g}$ yeast extract, $5 \mathrm{~g}$ peptone, $10 \mathrm{~g}$ glucose, and $16 \mathrm{~g}$ agar per liter, $\mathrm{pH}$ 7.2). Dead bacteria used for control were heat-killed at $100^{\circ} \mathrm{C}$ for $1 \mathrm{~h}$.

\section{Plant material.}

Arabidopsis thaliana L. (ecotype Columbia) suspension cells were grown at $24 \pm 2{ }^{\circ} \mathrm{C}$, under continuous white light (40 $\mu \mathrm{E} \mathrm{m}^{-2} \mathrm{~s}^{-1}$ ), with rotation shaking at $120 \mathrm{rpm}$ in a 1-liter roundbottom flask containing $300 \mathrm{ml}$ of Gamborg culture medium, pH 5.8. Cells were subcultured weekly by a 10 -fold dilution in fresh medium (Bouizgarne et al. 2006; Errakhi et al. 2008).

\section{Quantification of cell death.}

Cell viability was assayed using the vital dye Evans Blue (EB) (Errakhi et al. 2008). A. thaliana cell suspensions (500 $\mu \mathrm{l})$ infected with different bacterial suspensions during different time periods were incubated for $10 \mathrm{~min}$ in $\mathrm{EB}$ to a final concentration of $0.001 \%$ in $0.1 \mathrm{M}$ phosphate-buffer, $\mathrm{pH} 7$. Cells that accumulated EB were considered dead. A total of 500 cells were counted for each infection.

\section{Measurement of electrolyte leakage.}

Electrolyte leakage was measured from the clear supernatant of cultured cells infected with bacterial suspensions containing bacteria at $10^{8} \mathrm{CFU} \cdot \mathrm{ml}^{-1}$ that were incubated at $24 \pm 2{ }^{\circ} \mathrm{C}$, under continuous white light $\left(40 \mu \mathrm{E} \mathrm{m}^{-2} \mathrm{~s}^{-1}\right)$, with rotation shaking in flasks containing $10 \mathrm{ml}$ of solution. Conductivity was measured every $2 \mathrm{~h}$ with a SevenMulticonductimeter (Mettler Toledo, Viroflay, France).

\section{Pectate lyase assays.}

Pectate lyase activities were measured by monitoring the unsaturated oligogalacturonates accumulated after the enzymatic cleavage of $0.5 \%(\mathrm{wt} / \mathrm{vol})$ polygalacturonate (PGA). The assay was performed in $750 \mu \mathrm{l}$ of substrate solution (0.5\% PGA),
$200 \mu \mathrm{l}$ of clear supernatant of each treatment, $37.5 \mu \mathrm{l}$ of $5 \times$ $10^{-4} \mathrm{M} \mathrm{CaCl}_{2}$, and $512.5 \mu \mathrm{l}$ of $0.1 \mathrm{M}$ Tris- $\mathrm{HCl}, \mathrm{pH}$ 8.5. After incubation for $1 \mathrm{~h}$ at $30^{\circ} \mathrm{C}$, the reaction was stopped by heating at $100^{\circ} \mathrm{C}$ for $20 \mathrm{~min}$. Products resulting from sodium polypectate degradation were followed at $235 \mathrm{~nm}$ (Dinu et al. 2007; Pissavin et al. 1998).

\section{Pathogenicity test on potato slices.}

Fresh potatoes (cv. Agatha) were washed and chopped into equal pieces with a sterile borer. $P$. carotovorum strains $132 \mathrm{C}$, 1349, 1359, 1351, and CFPB5980 were cultured, and the concentrations were adjusted to $10^{2}, 10^{4}$, or $10^{8} \mathrm{CFU} \cdot \mathrm{ml}^{-1}$. Twelve potato slices were inoculated for each concentration. They were incubated at $30^{\circ} \mathrm{C}$ for $24 \mathrm{~h}$, and the maceration areas were quantified.

\section{ACKNOWLEDGMENTS}

We thank A. M. Pennarun for fruitful discussions and M. Hodges (IBP, Université Paris-Sud 11, Orsay, France) for carefully reading the manuscript. We also thank the editor and reviewers for fruitful comments. Financial support was provided by the Ministère de l'Enseignement Supérieur et de la Recherche to LEM-EA3514 and the Ministère des Affaires Etrangères et Européennes to Programme de Recherche Agronomique pour le Développement 07-07.

\section{LITERATURE CITED}

Aittamaa, M., Somervuo, P., Pirhonen, M., Mattinen, L., Nissinen, R., Auvinen, P. and Valkonen, J. P. 2008. Distinguishing bacterial pathogens of potato using a genome-wide microarray approach. Mol. Plant Pathol. 9:705-17

Atkinson, M. M., Baker, C. J., and Collmer A. 1986. Transient activation of plasmalemma $\mathrm{K}^{+}$efflux and $\mathrm{H}^{+}$influx in tobacco by a pectate lyase isozyme from Erwinia chrysanthemi. Plant Physiol. 82:142-146.

Barnard, A. M. L., and Salmond G. P. C. 2007. Quorum sensing in Erwinia species. Anal. Bioanal. Chem. 387:415-423.

Barras, F., Van Gijsegem, F., Chatterjee, A. 1994. Extracellular enzymes and pathogenesis of soft rot Erwinia. Phytopathology 32:201-234.

Bouizgarne, B., El-Maarouf-Bouteau, H., Frankart, C., Reboutier, D., Madiona, K., Pennarun, A. M., Monestiez, M., Trouverie, J., Amiar, Z., Briand, J., Brault, M., Rona, J. P., Ouhdouch, Y., El Hadrami, I., and Bouteau, F. 2006. Early physiological responses of Arabidopsis thaliana cells to fusaric acid: Toxic and signalling effects New Phytol. 169:209-218.

Collmer, A. 1983. The role of pectic enzymes in plant pathogenesis. Plant Physiol. 71:118-121.

Corbett, M., Virtue, S., Bell, K., Birch, P., Burr, T., Hyman, L., Lilley, K., Poock, S., Toth, I., and Salmond, G. 2005. Identification of a new quorum-sensing-controlled virulence factor in Erwinia carotovora subsp. atroseptica secreted via the type II targeting pathway. Mol. PlantMicrobe Interact. 18:334-342.

Darrasse, A., Priou, S., Kotoujansky, A., and, Bertheau, Y. 1994. PCR and restriction fragment length polymorphism of a pel gene as a tool to identify Erwinia carotovora in relation to potato diseases. Appl. Environ. Microbiol. 60:1437-1443.

Dinu, D., Nechifor, M. T., Stoian, G., Costache, M., and Dinischiotu, A. 2007. Enzymes with new biochemical properties in the pectinolytic complex produced by Aspergillus niger MIUG 16. J. Biotechnol. 131:128-137.

Duarte, V., De Boer, S. H., Ward, L. J., and de Oliveira, A. M. R. 2004 Characterization of atypical Erwinia carotovora strains causing blackleg of potato in Brazil. J. Appl. Microbiol. 96:535-545.

Errakhi, R., Meimoun, P., Lehner, A., Vidal, G., Briand, J., Corbineau, F., Rona, J. P., and Bouteau, F. 2008. Anion channel activity is necessary to induce ethylene synthesis and programmed cell death in response to oxalic acid. J. Exp. Bot. 59:3121-9.

El Hassouni, M., Chambost, J. P., Expert, D., Van Gijsegem, F., Barras, F. 1999. The minimal gene set member $m s r A$, encoding peptide methionine sulfoxide reductase, is a virulence determinant of the plant pathogen Erwinia chrysanthemi. Proc. Natl. Acad. Sci. U.S.A. 96:887-892.

Gross, D. C., Powelson, M. L., Regner, K. M., and Radamaker, G. K. 1991. A bacteriophage-typing system for surveying the diversity and distribution of strains of Erwinia carotovora in potato fields. Phytopathology 81:220-226. 
Helias, V., Le Roux, A. C., Bertheau, Y., Andrivon, D., Gauthier, J. P., and Jouan, B. 2004. Characterisation of Erwinia carotovora subspecies and detection of Erwinia carotovora subsp. atroseptica in potato plants, soil and water extracts with PCR-based methods. Eur. J. Plant Pathol. 104:685-699.

Holeva, M. C., Bell, K. S., Hyman, L. J., Avrova, A. O., Whisson, S. C., Birch, P. R., and Toth, I. K. 2004. Use of a pooled transposon mutation grid to demonstrate roles in disease development for Erwinia carotovora subsp. atroseptica putative type III secreted effector (DspE/A) and helper (HrpN) proteins. Mol. Plant-Microbe Interact. 17:943-950.

Hugouvieux-Cotte-Pattat, N., Condemine, G., Nasser, W., and Reverchon, S. 1996. Regulation of pectinolysis in Erwinia chrysanthemi. Annu. Rev. Microbiol. 50:213-57.

Kariola, T., Palomäki, T. A., Brader, G., and Palva, E. T. 2003. Erwinia carotovora subsp. carotovora and Erwinia-derived elicitors HrpN and PehA trigger distinct but interacting defense responses and cell death in Arabidopsis. Mol. Plant-Microbe Interact. 16:179-187.

Laasik, I., Andresen, L., and Mae, A. 2006. Type II quorum sensing regulates virulence in Erwinia carotovora ssp carotovora. FEMS (Fed. Eur. Microbiol. Soc.) Microbiol. Lett. 258:227-234

Mäki-Vlakama, T., and Karjalainen, R. 2008. Differentiation of Erwinia carotovora subsp. atroseptica and carotovora by RAPD-PCR. Ann. Appl. Biol. 125:301-309.

Mattinen, L., Tshuikina, M., Mäe, A., and Pirhonen, M. 2004. Identification and characterization of Nip, necrosis-inducing virulence protein of Erwinia carotovora subsp. carotovora. Mol. Plant-Microbe Interact. 17:1366-1375.

Parent, J. G., Lacroix, M., Pagé, D., Vézina, L., and Végiard, S. 1996. Identification of Erwinia carotovora from soft rot diseased plant by random amplified polymorphic DNA (RAPD) analysis. Plant Dis. 80:494-499.

Pemberton, C. L., Whitehead, N. A., Sebaihia, M., Bell, K. S., Hyman, L. J., Harris, S. J., Matlin, A. J., Robson, N. D., Birch, P. R., Carr, J. P., Toth, I K., and Salmond, G. P. 2005. Novel quorum-sensing-controlled genes in Erwinia carotovora subsp. carotovora: Identification of a fungal elicitor homologue in a soft-rotting bacterium. Mol. Plant-Microbe Interact. 18:343-353

Perombelon, M. C. M. 2002. Potato diseases caused by soft rot Erwinias: An overview of pathogenesis. Plant Pathol. 51:1-12.

Pissavin, C., Robert-Baudouy, J., and Hugouvieux-Cotte-Pattat, N. 1998 Biochemical characterization of the pectate lyase PelZ of Erwinia chrysanthemi 3937. Biochim. Biophys. Acta 1383:188-196.

Reboutier, D., and Bouteau, F. 2008. Harpins and ion channels modulations: Many ways to die. Plant Signal Behav. 3:314-316.

Seo, S. T., Furuya, N., Lim, C. K., Takanami, Y., and Tsuchiya, K. 2002. Phenotypic and Genetic Diversity of Erwinia carotovora ssp. carotovora strains from Asia. J. Phytopathol. 150:120-127.

Sledi, W., Jafra, S., Waleron, M., and Cojkowska, E. 2000. Genetic diversity of Erwinia carotovora strains isolated from infected plants grown in Poland. EPPO Bulletin 30:403-407.

Toth, I. K., Pritchard, L., and Birch, P. R. 2006. Comparative genomics reveals what makes an enterobacterial plant pathogen. Annu. Rev. Phytopathol. 44:305-36.

van Loon, L. C., Bakker, P. A. H. M., van der Heijdt, W. H. W., Wendehenne, D., and Pugin, A. 2008. Early responses of tobacco suspension cells to rhizobacterial elicitors of induced systemic resistance. Mol. Plant-Microbe Interact. 21:1609-1621.

Yap, M. N., Barak, J. D., and Charkowski, A. O. 2004. Genomic diversity of Erwinia carotovora subsp. carotovora and its correlation with virulence. Appl. Environ. Microbiol. 70:3013-3023. 